\title{
Pastoral community practices, microbial quality and associated health risks of raw milk in the milk value chain of Nakasongola District, Uganda
}

Samuel Majalija ${ }^{1 *}$ (D), Gabriel Tumwine ${ }^{1}$, Juliet Kiguli², James Bugeza', Marvin Apollo Ssemadaali ${ }^{1}$, Hebert Brian Kazoora ${ }^{3}$, Esther Namukose Muwanguzi ${ }^{4}$, Noelina Nantima ${ }^{5}$ and Richard Tuyiragize ${ }^{6}$

\begin{abstract}
The informal milk value chain in Uganda controls most of the raw marketed milk, albeit of poor quality. A study was conducted to assess the milk handling practices, the bacterial quality and the associated health concerns of raw milk along the informal milk value in Nakasongola District. The cross-sectional study used both qualitative and quantitative methods to obtain information from key players. The qualitative data was categorized and presented into emerging themes. Bacterial contamination of 200 milk samples was determined by morphological and biochemical tests. The antibiotic susceptibility test was done by the disc diffusion method.

Hand milking was carried out mainly by men (92.5\%), and most never or rarely practised hand washing (67.5\%) during milking. Milk was mainly delivered to mobile milk-collecting centres located under tree shades (50\%). The quality of raw milk was affected by poor hygienic, handling and transportation practices. Most participants (75\%) were aware of the dangers of drinking raw milk and the requirements to transport milk in metallic cans. Viable bacterial counts above the recommended limit were recorded in 76 samples (38\%) that included Staphylococcus aureus (46\%), coagulase-negative Staphylococcus (29\%), Escherichia coli (12\%), Streptococcus agalactiae (8\%) and Salmonella spp. (5\%). The overall antibiotic resistance was 45\% (34/76), which included resistant isolates of S. aureus (17/34), coagulase-negative Staphylococcus (11/22), S. agalactiae (3/6), Salmonella spp. (2/4) and E. coli (2/9).

The raw milk contaminated with antibiotic drug-resistant bacterial pathogens is of public health concern. Thus, measures to improve the quality of milk need to be designed for the pastoral community in Nakasongola district.
\end{abstract}

Keywords: Antimicrobial drug resistance, Bacterial pathogens, Cattle, Focused group discussions, Informal markets, Raw milk

\section{Introduction}

Agriculture is the main sector of Uganda's economy, supporting livelihoods of $69 \%$ of the current workforce (UBOS 2017). Livestock, particularly cattle, is reared under communal grazing and traditional dairy production systems among the pastoral communities in the cattle corridor, a vast savannah grassland which stretches from the southwest of Uganda to the northeastern borders for over 84,

\footnotetext{
* Correspondence: saraali67@gmail.com; saraali67@covab.mak.ac.ug ${ }^{1}$ School of Biosecurity, Biotechnical and Laboratory Sciences, College of Veterinary Medicine, Animal Resources and Biosecurity (COVAB), Makerere University, P.O. Box 7062, Kampala, Uganda

Full list of author information is available at the end of the article
}

$000 \mathrm{~km}^{2}$ (FAO 2018). This supports about $75 \%$ of the 11.4 million cattle in the country (UBOS 2017).

Essentially, livestock provides nutritional and income security as well as strengthens the resilience of the pastoralist communities (Thornton 2010). Presently, annual milk production in Uganda is in excess of 1.5 billion litres, compared to 365 million litres in 1991 (UBOS 2017; Kjær and Mwebaze 2013; Mbowa et al. 2012), which can be attributed to private sector involvement (Kjær and Mwebaze 2013; Mbowa et al. 2012). Uganda's dairy sector contributes more than $50 \%$ of total output of the country's GDP from agriculture (UBOS 2017) and is earmarked as a priority livestock investment area for improving household incomes and livelihoods (Mbowa et al. 2012). 
At present about $70 \%$ of the milk is marketed and 30\% consumed by the farming households. Between 10-20\% of the marketed milk is processed, while $70 \%$ is marketed raw (Ssajjakambwe et al. 2017). The informal marketing system trades in raw milk, disregarding the international standards of quality, pasteurization and use of cold-chain facilities (Omore and Baker 2011).

Milk is the main source of animal-based proteins and other micronutrients that are easily accessed by the poor, for example in Zimbabwe (Paraffin et al. 2018). Its consumption has been associated with improved dietary outcomes especially for women and children in sub-Saharan Africa (Wiley 2009). Also households that regularly consume milk in rural Uganda have recorded better health outcomes than non-milk consumers (Dobson and Combs 2005). On the other hand, the high nutritive value and water content of milk support the growth of bacterial pathogens (Ondieki et al. 2017) such as Salmonella, Staphylococcus or Escherichia coli that can cause milk-borne illnesses (Gwandu et al. 2018; Kateete et al. 2013). These may originate from the infected cows, the milk handlers, the equipment and/or the unhygienic environment (Kateete et al. 2013, Swai and Schoonman 2011; Kaneene et al. 2016).
The use of antibiotics in cattle production among the pastoralists (Ssajjakambwe et al. 2017; Ampaire et al. 2016) is a leading cause of antibiotic resistance of bacterial pathogens from cattle in Uganda (Ampaire et al. 2016; Oliver et al. 2011). Often, the prolonged use of antibiotics in udder infections exerts selection pressure which promotes resistant bacteria phenotypes (Oliver et al. 2011). These are shed in milk and can lead to milk-borne infections with severe consequences among the consumers (Kuipers et al. 2016; Gwandu et al. 2018).

Whereas consumers' quest for wholesome quality milk is paramount, attaining raw milk of acceptable quality remains a challenge for the informal milk value chain. Contamination of milk is associated with the transmission of resistant bacteria to consumers, causing severe milk-borne illnesses that are hard to treat with the available antibiotic drugs (Krahulcová et al. 2018; Sobur et al. 2019). Therefore, this study assessed the milk handling practices, the bacterial quality and public health risks of raw milk in the informal milk value chain in Nakasongola district. The results will contribute to strategies for improving the quality of milk and economic returns for the pastoral community in Nakasongola.

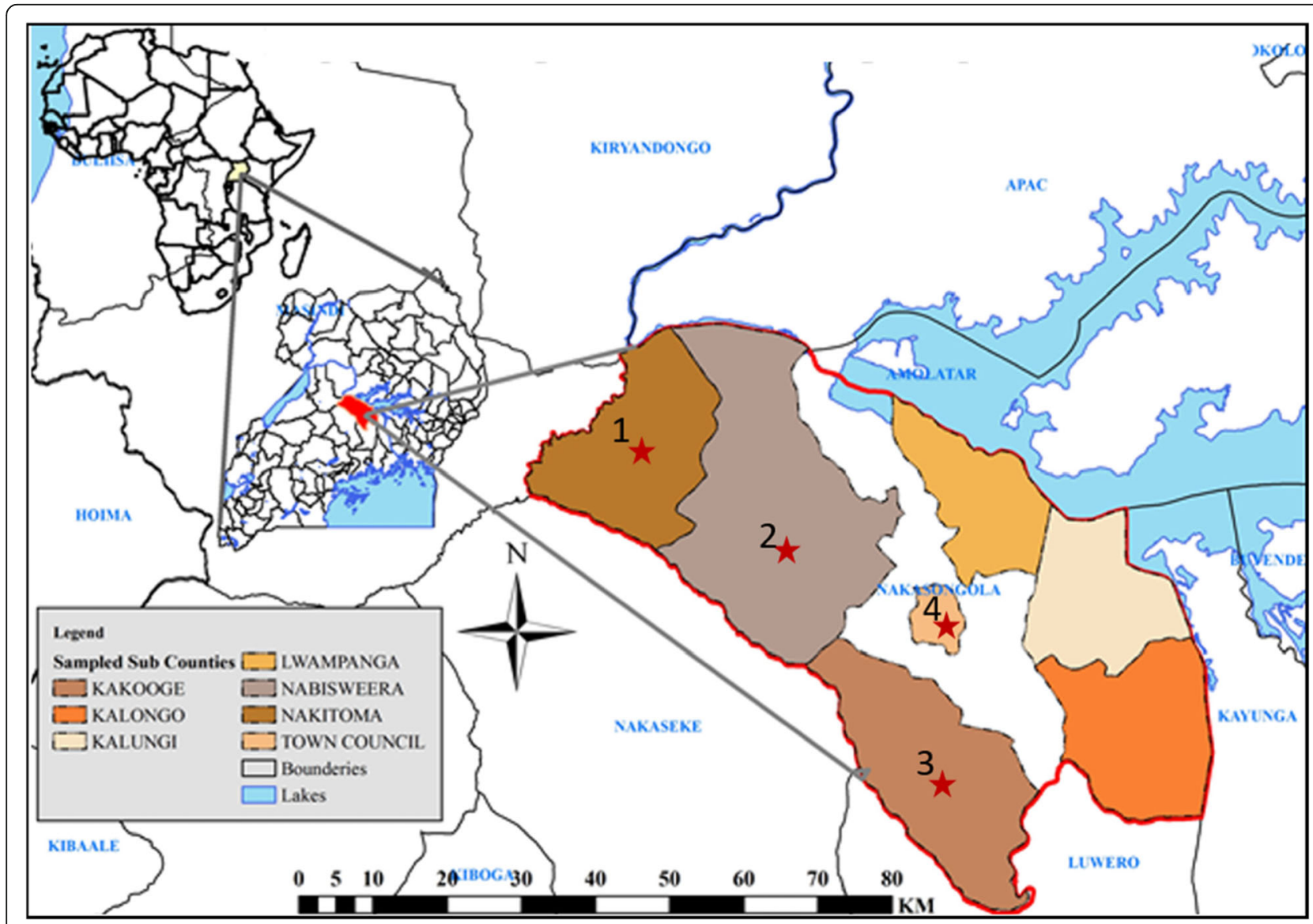

Fig. 1 Selected study sub-counties in Nakasongola district. 1, Nakitoma; 2, Nabiswera; 3, Kakooge; and 4, Nakasongola Town Council 


\section{Study area}

The study was conducted in the pastoralist community of Nakasongola District which lies within the cattle corridor of Uganda. This zone is sparsely populated, and its economy is driven by rain-fed agricultural and pastoral livestock husbandry practices. Nakasongola is located between latitudes 055N 140 'N and Longitudes 31 55E and 32 50E, and lies in between a transition southern zone with a clear bimodal rainfall and the northern zone which has a unimodal rainfall pattern. This is an area characteristic of water stress and prone to desertification (Lufafa 2006). The District has a mix of ethnic groups including Baganda, Baruuli, Banyankore and Banyarwanda, who derive their livelihoods mainly from sale of raw milk, meat, cattle and other livestock products. The District has one of the highest cattle densities in Uganda with over 150 cattle per square kilometre and 3050 cattle per household. The estimated cattle population is in excess of 222,000 heads of cattle, with $90 \%$ of the indigenous long-horned Ankole breed. Fencing of farms is practised by a segment of wealthy households, while a majority raise their cattle on a communal grazing system, with shared water reservoirs across the District. Due to prolonged droughts and in the dry season, communities move their animals in search for water and pastures towards the shores of Lake Kyoga.

The study was carried out from June to August 2017 in four of the seven sub-counties, namely Nabiswera, Nakitoma, Kakooge and Nakasongola Town Council (Fig. 1). These counties were purposively selected because a majority of households keep cattle and sell milk through the milk-collecting centres located in the area. The inhabitants also derive their livelihoods mainly from sale of raw milk and live cattle.

\section{Materials and methods}

\section{Study design and sampling}

This was a cross-sectional study that used both qualitative and quantitative research approaches. The qualitative study utilized focus group discussions (FGDs) and key informant interviews (KIIs) for data collection. Both KII and FGD participants were purposively selected. Four FGDs were carried out in groups of 9-11 participants who included farmers, milk vendors, transporters (bicyclists and motorcyclists), middle men, dairy cooperatives and other key persons involved in the milk value chain. In each FGD, the different stakeholder types were combined because the participants were primarily cattle keepers who also engaged in other activities in the milk value chain. This diversity was anticipated to enrich the discussions.

A total of four key informants in charge of subcounties and responsible for veterinary extension services were selected. Deliberate effort was made to interview both men and women, especially those
Table 1 Composition of the different focus group discussions from Nakasongola district

\begin{tabular}{|c|c|c|c|c|}
\hline \multirow{2}{*}{$\begin{array}{l}\text { Focus group } \\
\text { discussion number }\end{array}$} & \multirow[t]{2}{*}{ Stakeholders } & \multicolumn{2}{|c|}{ Number of } & \multirow[t]{2}{*}{ Total } \\
\hline & & Men & Women & \\
\hline \multirow[t]{5}{*}{ FDG $1 N=10$} & i. Cattle farmers & 2 & 1 & 3 \\
\hline & $\begin{array}{l}\text { ii. Bicycle mobile milk } \\
\text { vendors }\end{array}$ & 2 & 0 & 2 \\
\hline & iii. Motorcycle milk vendors & 2 & 0 & 2 \\
\hline & $\begin{array}{l}\text { iv. Mobile milk vendor } \\
\text { centres }\end{array}$ & 0 & 2 & 2 \\
\hline & $\begin{array}{l}\text { v. Livestock dairy } \\
\text { cooperatives }\end{array}$ & 1 & 0 & 1 \\
\hline \multirow[t]{5}{*}{$\mathrm{FGD} 2 \mathrm{~N}=10$} & i. Cattle farmers & 2 & 1 & 3 \\
\hline & $\begin{array}{l}\text { ii. Bicycle mobile milk } \\
\text { vendors }\end{array}$ & 2 & 0 & 2 \\
\hline & iii. Motorcycle milk vendors & 2 & 0 & 2 \\
\hline & $\begin{array}{l}\text { iv. Mobile milk vendor } \\
\text { centres }\end{array}$ & 0 & 1 & 1 \\
\hline & $\begin{array}{l}\text { v. Livestock dairy } \\
\text { cooperatives }\end{array}$ & 1 & 1 & 2 \\
\hline \multirow[t]{5}{*}{ FGD $3 N=11$} & i. Cattle farmers & 2 & 1 & 3 \\
\hline & $\begin{array}{l}\text { ii. Bicycle mobile milk } \\
\text { vendors }\end{array}$ & 2 & 0 & 2 \\
\hline & iii. Motorcycle milk vendors & 2 & 0 & 2 \\
\hline & $\begin{array}{l}\text { iv. Mobile milk vendor } \\
\text { centres }\end{array}$ & 0 & 2 & 2 \\
\hline & $\begin{array}{l}\text { v. Livestock dairy } \\
\text { cooperatives }\end{array}$ & 2 & 0 & 2 \\
\hline \multirow[t]{5}{*}{ FGD $4 N=9$} & i. Cattle farmers & 1 & 2 & 3 \\
\hline & $\begin{array}{l}\text { ii. Bicycle mobile milk } \\
\text { vendors }\end{array}$ & 2 & 0 & 2 \\
\hline & iii. Motorcycle milk vendors & 2 & 0 & 2 \\
\hline & $\begin{array}{l}\text { iv. Mobile milk vendor } \\
\text { centres }\end{array}$ & 0 & 1 & 1 \\
\hline & $\begin{array}{l}\text { v. Livestock dairy } \\
\text { cooperatives }\end{array}$ & 1 & 0 & 1 \\
\hline Total & & 28 & 12 & 40 \\
\hline
\end{tabular}

regularly involved in the milk value chain, to obtain information regarding their activities (Table 1).

\section{Data collection for the qualitative study}

The research team used various methods to collect data. Direct observations were used to gather and record information about the various activities of farmers, milk vendors and distributors; activities which could compromise milk quality and safety along the value chain. All FGDs were conducted in the local language using an interview guide and a moderator to guide the discussions. A tape recorder was used with the verbal consent from the participants, and recordings were later transcribed into English. In addition, semi-structured interviews conducted with each of the 40 participants of the 
FGDs gave additional information on the milk handling by the different actors along the value chain.

\section{Milk sample collection and processing}

Two mobile milk-collecting centres from Kakooge and another one in Nakasongola Town Council were selected for milk sample collection, which was carried out between 9:30 am and 12:00 pm every Friday for 10 weeks. At each centre, the first 10 mobile milk vendors were selected and from each vendor a milk sample was obtained from a plastic can containing milk from multiple farms. Approximately $40 \mathrm{ml}$ of milk sample was aseptically obtained from each plastic can, and in total, 200 samples were collected. All samples were securely capped, labelled and kept at $4-8{ }^{\circ} \mathrm{C}$ on ice in a cooler box. These were then transported to the central diagnostic laboratory at the College of Veterinary Medicine, Animal Resources and Biosecurity (COVAB) where analysis started immediately.

\section{Bacterial isolation and identification}

The bacterial quality assessment of milk was carried by the viable bacterial count method to enumerate colonyforming units per millilitre $(\mathrm{cfu} / \mathrm{ml})$ of the milk samples. Briefly, serial dilutions of milk in peptone water from $10^{-1}$ to $10^{-5}$ in duplicates were made and cultured on standard plate count agar at $37^{\circ} \mathrm{C}$ for $24-48 \mathrm{~h}$. The number of colonies between 30 and 300 colonies per plate was counted and expressed as cfu/ml (Cowan et al. 1993).

For identification of bacteria, about $50 \mu \mathrm{l}$ of the milk sample was inoculated onto nutrient agar (Oxoid, Hampshire, England) and incubated at $37^{\circ} \mathrm{C}$ for $18-24 \mathrm{~h}$. Briefly, a discrete single colony was inoculated for each of the three selective media, namely Mac-Conkey agar (Mastgroup, Merseyside, UK), MSA agar (Oxoid, Hampshire, England) and Xylose-lysine-deoxycholate medium (HiMedia, India). The culture plates were incubated at $37^{\circ} \mathrm{C}$ for $18-24 \mathrm{~h}$ to isolate bacteria. These were then characterized using standard morphological and biochemical tests (Cowan et al. 1993). Pure cultures stored as glycerol stocks were used for further analysis.

\section{Antibiotic susceptibility testing}

The antibiotic susceptibility of bacterial isolates was determined using the modified Kirby-Bauer disc diffusion method (Hudzicki 2009). Briefly, an overnight bacterial inoculum (0.5 McFarland) was spread on Mueller-Hinton agar (Bio-Rad, France) and six antibiotic discs were placed on each plate. These contained ampicillin (Amp) $10 \mu \mathrm{g}$, amoxicillin (Amx) $25 \mu \mathrm{g}$, ceftriaxone (Cef) $30 \mu \mathrm{g}$, gentamycin (Gen) $30 \mu \mathrm{g}$, tetracycline (Tet) $30 \mu \mathrm{g}$ and vancomycin (Van) $30 \mu \mathrm{g}$ (Oxoid, Hampshire, England). S. aureus (ATCC 25923) was used as the control strain.

\section{Data management and analysis}

Responses from FGD transcripts were cross-checked to ensure completeness of data and analysed using content analysis (Kondracki et al. 2002). The data was categorized and presented into emerging themes including (i) key players in handling and transportation of milk in Nakasongola district, (ii) risky practices affecting the quality of milk and transmission of diseases from milk to humans and (iii) challenges to policies and regulation for the informal milk value chain. Descriptive analysis was used to summarize data from the questionnaire in the form of frequencies and percentages. A modified assessment of the farm hygiene index was used to generate scores for milk quality (Kaneene et al. 2016). The index scores categorized as low risk, score 1; moderate risk, scores 2-3; and high risk, scores 4-5 were then used to construct radar charts in Excel 2013. Data on the bacterial counts was first transformed to logarithm of colony-forming units per millilitre of sample $(\log \mathrm{cfu} / \mathrm{ml})$. The East African Community (EAC) acceptable level of the total bacterial counts for raw cow milk of $\leq 2 \times 10^{6} \mathrm{cfu} / \mathrm{ml}$ [https://law.resource.org/ pub/eac/ibr/eas.67.2006.html] was used to qualify contamination in raw milk samples.

The diameter of zonal clearance was measured in millimetres, and results were recorded as susceptible (S), intermediate (I) and resistant (R) according to CLSI, performance standards for antibiotic susceptibility testing (CLSI 2012).

\section{Results}

\section{Socio-demographic characteristics of the participants}

From the four sub-counties (Nabiswera, Nakitoma, Kakooge, and Nakasongola Town Council), a total of 40 participants were recruited into the FGDs. These included $12(30 \%)$ farmers, $8(20 \%)$ comprised of equal numbers of bicycle and motorcycle mobile milk vendors (M2Vs), while $6(15 \%)$ each were from mobile milk vendor centres $(\mathrm{MVc})$ and the livestock dairy cooperatives (LDCs). A majority (87.5\%) had at least 3 years of experience in dealing with the milk value chain and 28 (70\%) were males.

\section{Milk handling and transportation in Nakasongola District}

Table 2 describes the major aspects associated with handling and transportation of milk in Nakasongola. Hand milking was carried out mainly by men $(92.5 \%)$, of whom only $7.5 \%$ routinely washed hands before, $25 \%$ rarely or never washed hands while $42.5 \%$ cleaned their hands on the skin of cows. Most milkers (50\%) used a rod referred to as enkoni to restrain the calf while milking. Milk was collected from the farm mainly by M2Vs (80\%) using motorcycles $(70 \%)$ and in plastic cans $(75 \%)$. The MVc were mainly located under tree shades $(50 \%)$ or a verandah (25\%). The most frequently used milk adulterant was water 
Table 2 Milk handling and transportation in Nakasongola District

\begin{tabular}{|c|c|c|}
\hline Attribute & Frequency & Percentage \\
\hline \multicolumn{3}{|l|}{ Gender of hand milkers } \\
\hline Males & 37 & 92.5 \\
\hline Females & 3 & 7.5 \\
\hline \multicolumn{3}{|l|}{ Experience of handling milk } \\
\hline $0-2$ years & 5 & 12.5 \\
\hline $3-5$ years & 28 & 70 \\
\hline$>5$ years & 7 & 17.5 \\
\hline \multicolumn{3}{|l|}{ Washing hands before milking } \\
\hline Always & 3 & 7.5 \\
\hline Sometimes & 10 & 25 \\
\hline Rarely & 5 & 12.5 \\
\hline Never & 5 & 12.5 \\
\hline $\begin{array}{l}\text { Others (clean hands on the skin of } \\
\text { a cow between milking different cows) }\end{array}$ & 17 & 42.5 \\
\hline \multicolumn{3}{|l|}{ Restraining calf } \\
\hline Tie with rope & 10 & 25 \\
\hline Use a stick & 25 & 50 \\
\hline Use a hand to hit the calf & 10 & 25 \\
\hline \multicolumn{3}{|l|}{ Milk collectors } \\
\hline Farmer & 5 & 12.5 \\
\hline Mobile milk vendors (M2Vs) & 32 & 80 \\
\hline Others & 3 & 7.5 \\
\hline \multicolumn{3}{|l|}{ Mode of milk transport } \\
\hline Bicycle & 9 & 22.5 \\
\hline Motorcycle & 28 & 70 \\
\hline Vehicle & 3 & 7.5 \\
\hline \multicolumn{3}{|l|}{ Milk transportation containers } \\
\hline Plastic jerrycans & 30 & 75 \\
\hline Metallic cans & 7 & 17.5 \\
\hline Others & 3 & 7.5 \\
\hline \multicolumn{3}{|l|}{ Location of mobile milk vending centres } \\
\hline Verandah & 10 & 25 \\
\hline Under a tree shade & 20 & 50 \\
\hline Other mobile locations & 10 & 25 \\
\hline \multicolumn{3}{|l|}{ Test of milk quality control } \\
\hline Water adulteration with a hygrometer & 30 & 75 \\
\hline Smell & 5 & 12.5 \\
\hline Taste & 2 & 5 \\
\hline Colour change & 3 & 7.5 \\
\hline \multicolumn{3}{|l|}{ Common milk adulterants } \\
\hline Water & 28 & 70 \\
\hline Cassava/maize flower & 7 & 17.5 \\
\hline Herbs & 3 & 7.5 \\
\hline Chemicals & 2 & 5.0 \\
\hline
\end{tabular}

Data was obtained from the questionnaire interviews
(75\%); others include flour (cassava), herbs and chemicals (Table 2).

\section{Key players in milk handling and transportation in Nakasongola district}

M2Vs reported that they delivered pooled milk from several farms to the MVc and livestock dairy cooperative (LDC) within 4-6 h after milking (Fig. 2).

Between $2-5$ vendors operate the MVc, and each buys 400-1000l of milk, which is immediately transported on pick-up trucks at ambient temperature in plastic cans. It was observed that MVc operate in a dirty environment with no running water, handwashing or toilet facilities (Fig. 3).

Milk handling practices are shown in Fig. 4. Scores of 11 practices affecting the quality of raw milk were ranked, of which $8(73 \%)$ had scores of 3-5 that indicated poor quality of milk (Fig. 4). Cleaning milkers' hands on the skin of cows and poor hygiene of the milking environment were scored 5 , while unhygienic mobile milk-collecting centres and dirty water used to wash milking utensils scored 4 (Fig. 4). Broadly, these practices can be categorized into poor hygienic, handling and transportation practices of milk (Fig. 4).

\section{Awareness of the transmission of diseases from raw milk} Most participants in all the four FGDs (75\%) were aware of the dangers associated with drinking raw milk. They admitted either they themselves or someone in their households drank/drinks raw or half-cooked milk and also eat milk products produced from raw milk. Reasons given for drinking raw milk as quoted are (i) 'we have been drinking raw milk since we were little children and it has not caused us any harm' and (ii) 'we drink raw milk because it is good for our health, gives high nutrients to our bodies and keeps one stronger'.

\section{Policy issues and challenges for the informal milk value chain}

Most of the milk vendors and operators of MVc (80\%) were aware of the dangers of transporting milk in nonfood grade containers, particularly those made of plastics. Further, $75 \%$ were aware of the regulations and requirements for proper transportation of milk using metallic cans. However, it was deemed expensive to buy this equipment as participants quoted the right milk equipment is very expensive, we request the government to provide us with metallic cans or coolers at a subsided price or give loans at a low interest rate to buy these equipment'.

\section{Bacterial quality of milk and source of contamination in Nakasongola district}

A total of 200 milk samples were analysed for bacterial contamination. Of these, 76/200 (38\%) had bacterial 


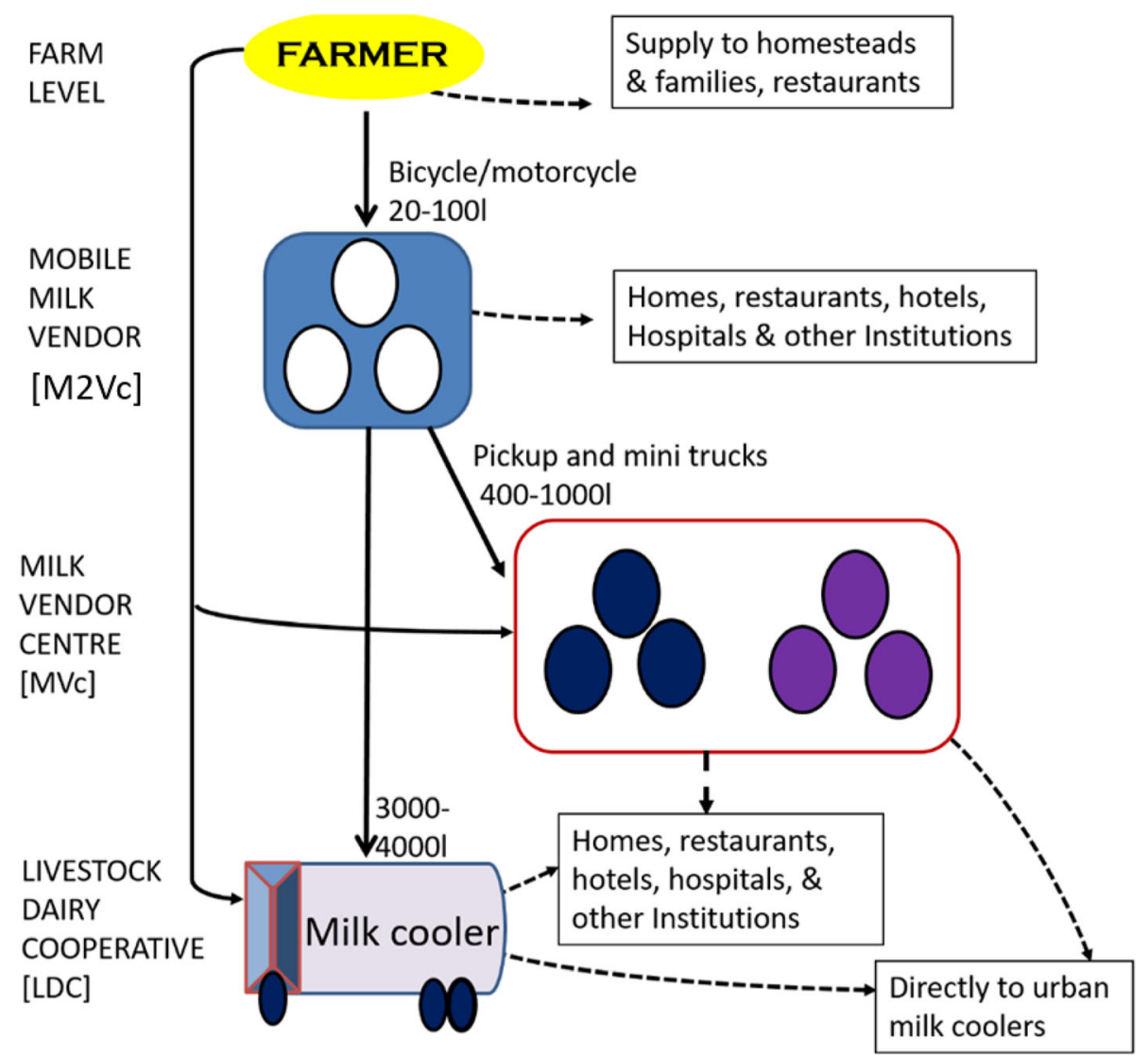

Fig. 2 Key players in the milk value chain in Nakasongola district. Practices affecting the quality of milk in the milk value chain in Nakasongola

contaminations above the recommended limits $(\leq 2 \times$ $\left.10^{6} \mathrm{cfu} / \mathrm{ml}\right)$. As in Table 2, staphylococcal organisms were the most common milk contaminant ( $n=57,75 \%)$, comprising of $S$. aureus $(n=35,46 \%)$ and CoNS $(n=22$, $29 \%)$ isolates. Other bacterial contaminants are E. coli $(n=9,12 \%), S$. agalactiae $(n=6,8 \%)$ and Salmonella spp. $(n=4,5 \%)$.

\section{Antibiotic-resistant bacterial isolates in raw milk from Nakasongola}

The frequency and patterns of antibiotic resistance in the bacterial isolates were determined. Out of 76 bacterial isolates, 35 (46\%) were resistant to at least one antimicrobial drug as follows: S. aureus, 17 of 34 (50\%); coagulase-negative Staphylococcus (CoNS), 11 of 22 (50\%); S. agalactiae, 3 of 6 (50\%); Salmonella spp., 2 of 4 (50\%); and E. coli, 2 of 9 (22\%). None of the isolates was resistant to vancomycin.

As shown in Fig. 5, the overall resistance of S. aureus to Amp, Amx and Gen was $82 \%(n=14), 59 \%(n=10)$ and $76 \%(n=13)$, respectively. Also $59 \%(n=10)$ and $29 \%(n=5)$ were resistant to Tet and Cef, respectively. Similarly, the overall resistance of CoNS isolates with respect to each drug; Amp, Amx, and Gen was (82\%, $n=9)$, while $55(n=6)$ and $36 \%(n=4)$ for Tet and Cef.

\section{Discussion}

The dairy sector in pastoral communities of Nakasongola District simultaneously operates within the formal and informal milk marketing channels. Although the informal milk sector is weakly organized with little to no support from the Ugandan government, it continues to handle the largest segment of the raw milk in Nakasongola and Uganda at large (80\%) (Ekou 2014), as well in East Africa (Makoni et al. 2014; Nyamwaro et al. 2018). In contrast to formal dairy cooperatives, the strategic location of informal $\mathrm{MVc}$ in the vicinity of farm-holds provides convenient options for collecting and marketing milk at the community level. MVc provide invaluable services of transporting milk from the remote areas of Nakasongola, especially during the rainy seasons when the murram dirt roads are impassable for cars (Staal and Kaguongo 2003). They link the pastoral communities to consumers in urban centres (Ashoke and Keshav 2002) and offer farmers immediate payments for the supplied milk (Mugendi 2013). Besides, the sale of raw milk provides business opportunities for the indigenous 


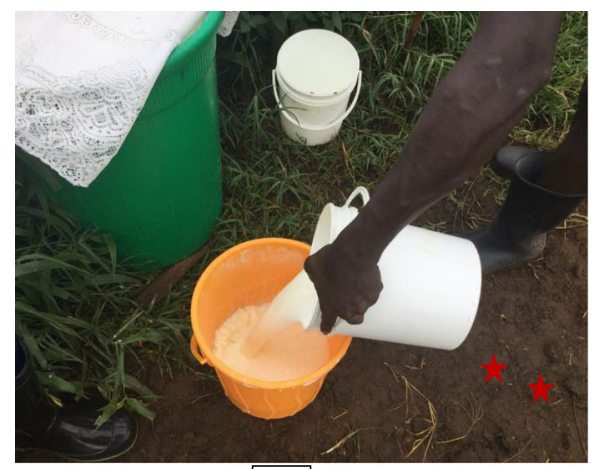

$\mathrm{A}$

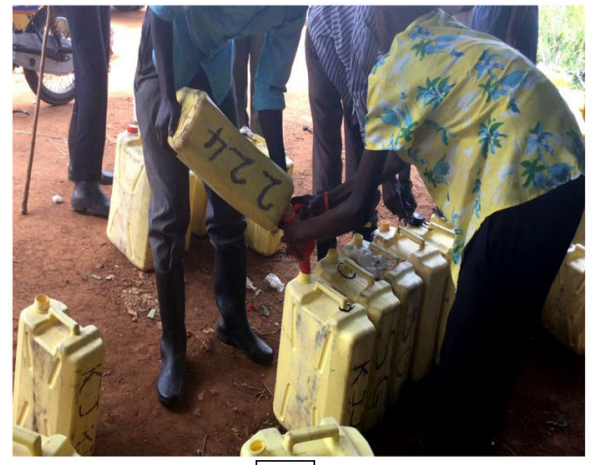

C

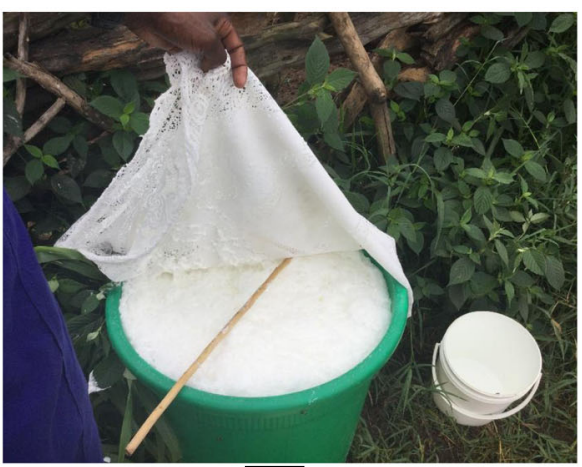

B

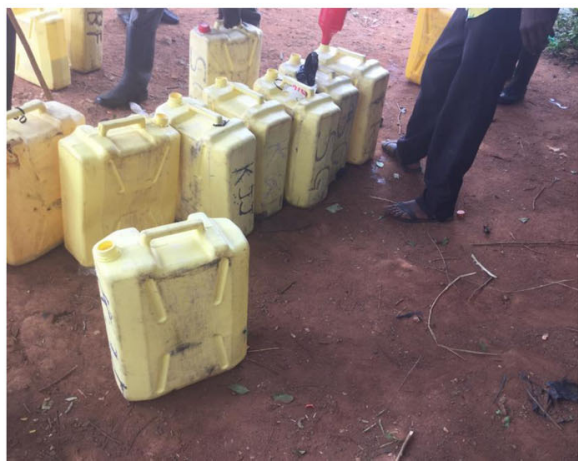

$\mathrm{D}$

Fig. 3 Milk handling practices in Nakasongola district. a Milk is dispensed in a plastic container. In the background is a green bucket for keeping large volume of milk. Also note the presence of dry cow dung marked by red stars. $\mathbf{b}$ Milk is protected with a cloth/towel from flies and dust. $\mathbf{c}$ A typical roadside mobile milk-collecting centre. Milk is dispensed from plastic cans by mobile milk vendors to other cans at the centre. $\mathbf{d}$ A mobile milk-collecting centre showing the poor hygiene. The environment is dusty or muddy and littered with garbage

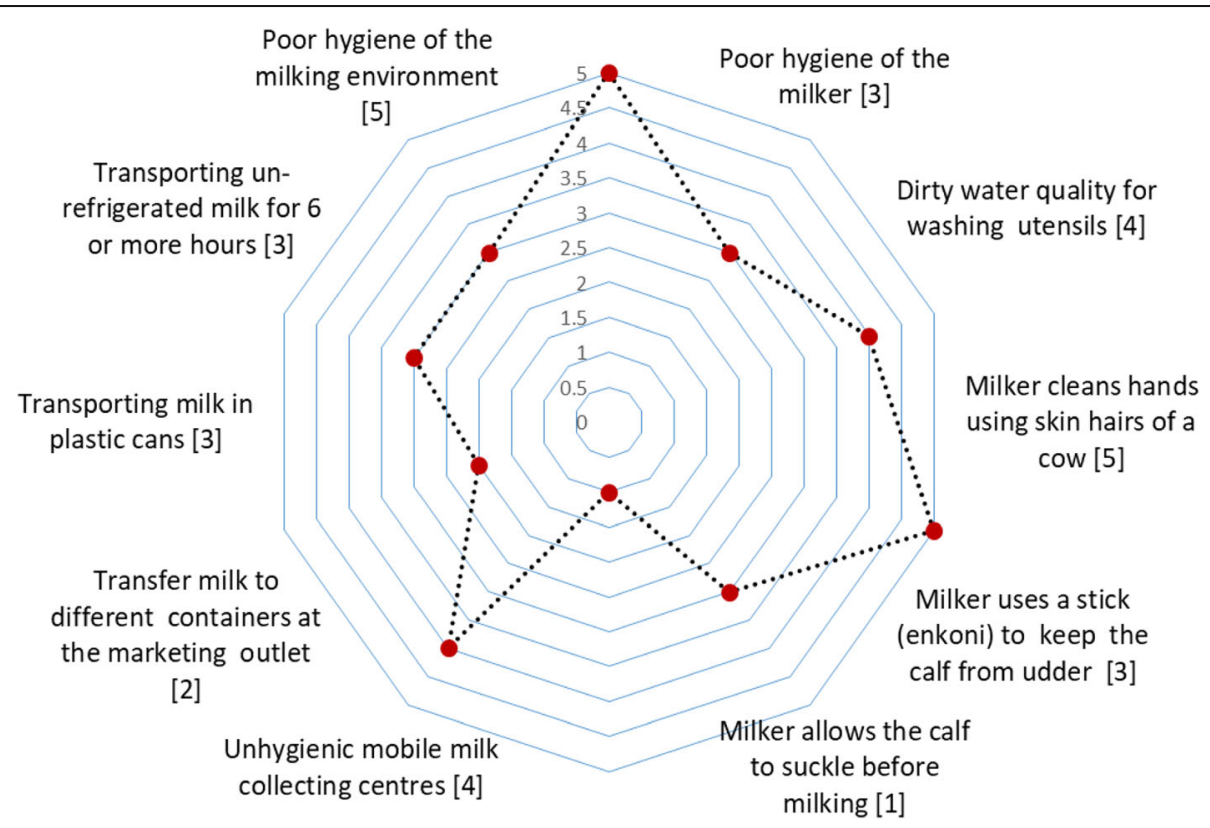

Fig. 4 Practices affecting the quality of milk. High risk, scores 4-5; moderate risk, scores 2-3; low risk, score 1 


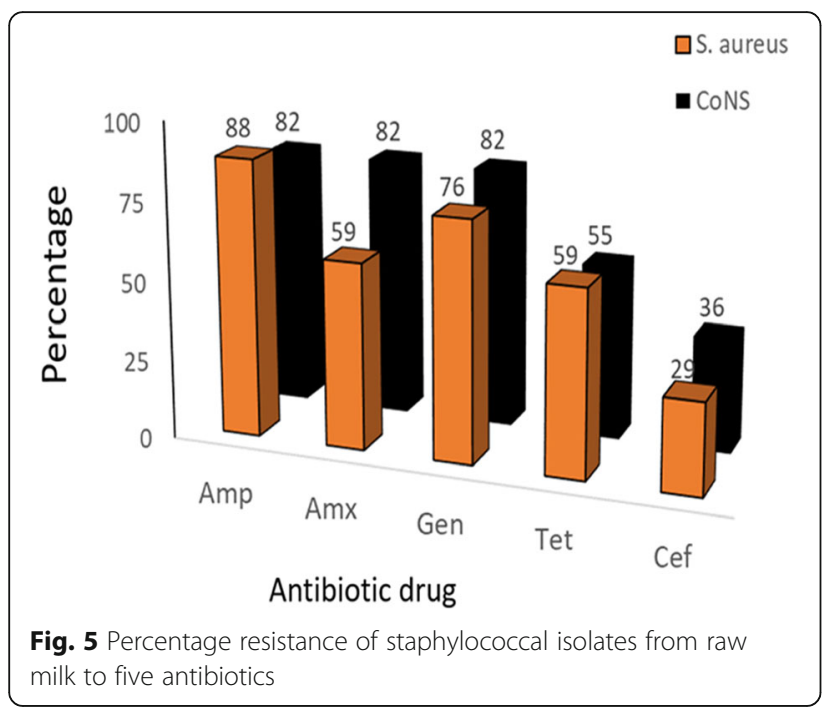

communities in the milk value chain, which consequently empowers the local communities (FAO 2007).

The consumption of raw milk is attractive to consumers with cultural beliefs and preferences for raw milk, particularly among the pastoralists in Uganda (Tumwine et al. 2015) and elsewhere in sub-Saharan Africa (Caudell et al. 2019; Ayele et al. 2017). Traditionally, raw milk is perceived to have health benefits (Amenu et al. 2019) and unique flavours, but these assertions lack scientific evidence. On the contrary, drinking raw milk is associated with transmission of diseases to consumers (Tumwine et al. 2015). Thus, treating of milk before consumption is highly recommended for the pastoralist communities, in order to prevent transmission of milk-borne infections especially among the vulnerable children.

Regardless of the benefits, efforts to enforce the use of metallic cans for milk handling in Uganda have remained futile. This has continued to cause conflicts between the regulators and players in the milk value chain (Ekou 2014). Although the quality of milk and farmers' incomes were increased with the introduction of metal cans in Kenya (Ndungu et al. 2016), the informal sector in Uganda has not yet adopted this practice. In part, this failure may be due to the high equipment cost, and the Government of Uganda may consider providing equipment support mechanisms for the pastoralist communities to engage competitively in the milk business. On the other hand, the pastoral communities are unwilling to invest in the purchase of equipment (Kabirizi 2006) due to the unresolved socio-cultural concerns (Kjær and Mwebaze 2013; Ekou 2014). This is because efforts to modernize livestock production may be seen as an attempt to dismantle and restructure the pastoralist way of life and a threat to their existence. Thus, it is necessary to engage the communities in decisionmaking and ownership of such technologies, rather than imposing unilateral government decisions. In concurrence, involving communities in problem-solving leads to more effective, feasible and responsive solutions and enhances the acceptance and legitimacy of decisions (De Weger et al. 2018). The most viable option is a gradual streamlining of the informal milk sector to secure the socio-economic well-being of stakeholders, backed by inclusive policies (Omore and Baker 2011), cognizant of the unique social-cultural context of the pastoral communities. This streamlining process would have to consider affirmative strategic interventions such as public sector investment in infrastructure, access to credit and training for the informal sector to engage competitively in the milk business.

One of our main purposes was to ascertain the quality of pooled milk at MVc, prior to its dispatch to the urban consumers. That $30 \%$ of milk samples had bacterial loads beyond the acceptable limits $\left(>/ 2 \times 10^{6} \mathrm{cfu} / \mathrm{ml}\right)$ confirms the challenges of handling raw milk through the informal value chain in Nakasongola. This was similar to previous studies in Uganda (Kaneene et al. 2016; Wangalwa et al. 2016) and elsewhere in Rwanda and Kenya, which reported higher bacterial loads for raw milk arriving at milk collection centres (Doyle et al. 2015; Ndungu et al. 2016). Given our observations and FGD and KII, we can surmise that the poor milk quality was due to poor practices along the milk value chain. The time lapse of 4-6h between milking and collection without refrigeration of milk augmented microbial multiplication. Besides, the plastic milk cans are a source of contamination that promotes bacterial proliferation. The rough surfaces of plastic containers prevent effective cleaning and sanitization, and this increases bacterial contamination of milk (Ayele et al. 2017). While motorcycles remain the major means of transportation of milk in Nakasongola, the milk was further exposed to long hours of high tropical heat. Subsequently, poor quality and similar observations have been reported in Zimbabwe and elsewhere (Amenu et al. 2019; Paraffin et al. 2018; Ayele et al. 2017).

Of note, milk constitutes an integral part of pastoralist communities' social life in Nakasongola District, and can be processed into sour milk, yoghurt, ghee and eshabwe, a traditional delicacy served on important ceremonial celebrations. There were various practices that could compromise the quality of milk. For instance, farmers never washed their hands before milking and instead cleaned their hands on the skin of the cows. This was similar to noted earlier where many farmers did not sufficiently clean their hands before milking (Wangalwa et al. 2016; Hofi 2011). The use of a rod known as enkoni to restrain the calf during milking could as well be a source of milk contamination, especially if the environment is littered with cow dung. Although the 
plastic buckets were covered with cloth, this may not guarantee improved hygiene; also the kraals were littered with cow dung that could be a source for milk contamination. We also observed a common practice of mixing milk from different farms by the milk vendors which could further compromise the quality of milk. The operation of MVc in unregulated dusty and dirty places that lacked toilets and running water facilities is a further concern to the quality of milk. Generally, the highlighted unhygienic milk handling practices compromise the quality of raw milk. It is thus crucial to adopt good milk handling practices that minimize contamination along the value chain if milk of acceptable quality is to be realized (Wangalwa et al. 2016; Sudhir and Kalule 2014).

In the present study, isolated bacterial contaminants of milk included E. coli, S. aureus, CoNS, S. agalactiae and Salmonella spp. Previously, similar bacterial contaminants were reported in milk from Uganda (Kateete et al. 2013; Kasozi et al. 2014). The bacterial isolate was $S$. aureus which could be from milk handlers that lacked appropriate protective wear and good hygienic practices (Table 3). Evidently, S. aureus is a commensal bacteria from nasal passages of healthy humans (Hanssen et al. 2017), and during coughing or sneezing, the bacteria shed into milk. Aside from humans, S. aureus and CoNS could be associated with sub-clinical mastitis which is common in milking cows in Uganda (Kateete et al. 2013; Kasozi et al. 2014). Although remaining undetected by most farmers, sub-clinical mastitis continues to be a source for milk bacterial contamination (Kateete et al. 2013; Hosseinzadeh and Saei 2014). Whether the major source of contamination was udder infection or from other external sources requires another study. S. agalactiae are associated entirely with udder infection, suggesting the occurrence of sub-clinical mastitis as the source. Salmonella spp. were probably shed by cattle and contaminated milk through the faecal matter. Previously, Salmonella strains were isolated from rectal faeces of cattle in Uganda (Kagirita et al. 2017); however, humans can also be a source of Salmonella. This is because infected food handlers have been associated with Salmonella contamination of ready-to-eat foods elsewhere
(Holman et al. 2014). E. coli is mainly an environmental bacteria, and its presence indicates transfer of the pathogens from the contaminated environment due to poor hygiene.

The bacterial pathogens isolated from the milk showed marked antibiotic resistance. A majority of $S$. aureus were resistant to Amp, Amx and Gen (82\%) which was higher than previously reported from milk in Uganda (Kateete et al. 2013; Kasozi et al. 2014), suggesting an increase in resistance of animal pathogens in the cattle corridor over the years. Antibiotic resistance is promoted by an excessive use and misuse of antibiotics in cattle production (Mukasa et al. 2012). Also the higher resistance to Tet in our study than in Kasozi et al.'s (2014) study (55\% vs 33\%) from the cattle corridor may be linked to the excessive use of tetracycline drugs by farmers. Tet is relatively cheap and readily available as over-the-counter drug used by the farmers in Uganda without veterinary supervision (Ssajjakambwe et al. 2017). However, further studies are needed to generate household data on antimicrobial use to provide conclusive evidence on the extent of antimicrobial resistance of milk-borne pathogens in the community.

We report $29 \%$ and $36 \%$ resistance of S. aureus and CoNS to Cef, respectively, which was unexpected because this drug was not used in cattle production in Uganda, but available for treatment of human S. aureus bloodstream infections (Lowe et al. 2017). This shows that antibiotic drug resistance is more extensive than previously thought among bacterial pathogens from cattle in Uganda. This suggests that beyond antibiotic use, there are other factors that probably promote the emergence of resistance and would necessitate future studies. It was surprising that $E$. coli showed the least resistance, contrasting with other previous studies (Kasozi et al. 2014). E. coli isolates were from the environment, where the antibiotic selection pressure was still low, rather than from cattle with higher antibiotic selection pressure (Table 3). That all pathogens were susceptible to vancomycin was expected since these drugs have not been used in animals and resistant strains have not emerged in cattle as yet. However, this finding was inconsistent

Table 3 Bacterial isolates associated with contamination of raw milk

\begin{tabular}{llll}
\hline Bacteria type & Number & Frequency & Probable source $^{\text {a }}$ \\
\hline S. aureus & 35 & 46 & Milk handlers, mastitic cows \\
CoNS & 22 & 29 & Milk handlers, mastitic cows \\
E. coli & 9 & 12 & Environment, cattle, humans \\
S. agalactiae & 6 & 8 & Cattle \\
Salmonella spp. & 4 & 5 & Cattle, humans \\
Total number and percentage & 76 & 100 & \\
\hline
\end{tabular}

${ }^{\mathrm{a}} \mathrm{S}$. aureus and CoNS are frequently shed from the nostrils of humans and infected udders of cows; $E$. coli is associated with human and cattle (animals) faecal matter and is shed into the soil and water; S. agalactiae is associated with infected udder while Salmonella can be shed by infected humans and cattle 
with the reports from Ethiopia in which most $S$. aureus were resistant to vancomycin (Ayele et al. 2017).

\section{Conclusion}

Undeniably, the informal milk markets of Nakasongola District are associated with poor quality milk contaminated with antibiotic drug-resistant bacterial pathogens that may be of public health concern. Thus, measures to improve the quality of milk need to be designed for the pastoral communities in Nakasongola district.

\section{Abbreviations}

Amp: Ampicillin; Amx: Amoxicillin; Cef: Ceftriaxone; Cfu: Colony-forming units; CoNS: Coagulase-negative Staphylococcus; COVAB: College of Veterinary Medicine, Animal Resources and Biosecurity; FGDs: Focus group discussions; Gen: Gentamycin; LDCs: Livestock dairy cooperatives; M2Vs: Mobile milk vendors (bicycle and motorcycle riders); MVc: Mobile milk vendor centres; Tet: Tetracycline; Van: Vancomycin

\section{Acknowledgements}

The authors acknowledge the key cattle keepers, managers of livestock dairies, district veterinary offices and other technical staff and the political leaders in Nakasongola District for the immeasurable support given during the study. Special thanks to the National Agriculture Research Organization through CGS for providing the research grant. Mr. Lubowa-Musisi, Laboratory Manager of the Microbiology Diagnostic Laboratory, College of Veterinary Medicine, Animal Resources and Biosecurity is thanked for the support.

\section{Authors' contributions}

$S M, G T, J B, J K, M S, N N$, ENM, RT and HK participated in the study conception, design and writing proposal; SM, GT, JK, MS, ENM and JB participated in the sample collection and laboratory analysis; SM, GT, JK, NN, RT, JB and HK participated in coordination and supervision; GT, JK, RT, JB and SM participated in the data analysis and drafted the manuscript; SM, GT, MS, JB, JK and NN edited the manuscript. All authors read and approved the final manuscript.

\section{Funding}

This work was supported by the National Agricultural Research Organization (NARO-Uganda) grant number CGS 2/14/14.

\section{Availability of data and materials}

The datasets used and/or analysed during the current study are available from the corresponding author upon request.

\section{Ethics approval and consent to participate}

All subjects gave their informed consent for inclusion before they participated in the study. The study was conducted in accordance with the Declaration of Helsinki, and the protocol was approved by the Ethics Committee of Makerere University College of Veterinary Medicine, Animal Resources and Biosecurity.

\section{Consent for publication}

Not applicable.

The authors declare that the manuscript does not contain any personally identifiable information and all personal data is anonymous.

\section{Competing interests}

The authors declare that they have no competing interests.

\section{Author details}

${ }^{1}$ School of Biosecurity, Biotechnical and Laboratory Sciences, College of Veterinary Medicine, Animal Resources and Biosecurity (COVAB), Makerere University, P.O. Box 7062, Kampala, Uganda. 'Department of Community Health and Behavioural Sciences, Makerere University School of Public Health, P.O. Box 7062, Kampala, Uganda. ${ }^{3}$ Africa Field Epidemiology Network (AFENET), Kampala, Uganda. ${ }^{4}$ Veterinary Public Health, Ministry of Health, Uganda Government, Kampala, Uganda. ${ }^{5}$ Ministry of Agriculture, Animal
Industry and Fisheries (MAAIF), Entebbe, Uganda. ${ }^{6}$ College of Business and Management Sciences, Makerere University, P.O. Box 7062, Kampala, Uganda.

Received: 16 October 2019 Accepted: 2 January 2020

Published online: 14 February 2020

\section{References}

Amenu, K., B. Wieland, B. Szonyi, et al. 2019. Milk handling practices and consumption behavior among Borana pastoralists in southern Ethiopia. Journal of Health, Population and Nutrition 38: 6. https://doi.org/10.1186/ s41043-019-0163-7.

Ampaire, L., A. Muhindo, P. Orikiriza, J. Mwanga-Amumpaire, L. Bebell, and Y. Boum. 2016. A review of antimicrobial resistance in East Africa. African Journal of Laboratory Medicine 5 (1): 432.

Ashoke, K.G., and L.M. Keshav. 2002. Milk marketing channels in Bangladesh: A case study of three villages from three districts. Journal of International Development and Cooperation 8 (2): 87-101.

Ayele, Y., F.D. Gutema, B.M. Edao, R. Girma, T.B. Tufa, T.J. Beyene, F. Tadesse, et al. 2017. Assessment of Staphylococcus aureus along milk value chain and its public health importance in Sebeta, central Oromia, Ethiopia. BMC Microbiology. https://doi.org/10.1186/s12866-017-1048-9.

Caudell, M.A., P.V. Charoonsophonsak, A. Miller, et al. 2019. Narrative risk messages increase uptake and sharing of health interventions in a hard-toreach population: A pilot study to promote milk safety among Maasai pastoralists in Tanzania. Pastoralism 9: 7. https://doi.org/10.1186/s13570-0190142-z.

CLSI, ed. 2012. Performance standards for antibiotic disk susceptibility tests, approved standard, 7th ed., CLSI document M02-A11. Wayne: Clinical and Laboratory Standards Institute.

Cowan, S.T., K.J. Steel, G.I. Barrow, and R.K.A. Feltham. 1993. Cowan and Steel's manual for the identification of medical bacteria. 3rd ed. Cambridge: Cambridge University Press.

De Weger, E., N. Van Vooren, K.G. Luijkx, C.A. Baan, and H.W. Drewes. 2018. Achieving successful community engagement: A rapid realist review. BMC Health Services Research. https://doi.org/10.1186/s12913-018-3090-1.

Dobson, W., and D. Combs. 2005. Prospects for Uganda's dairy industry. University of Wisconsin-Madison, Babcock Institute for International Dairy Research and Development, Discussion Papers https://ageconsearch.umn.edu/bitstream/3 7492/2/2005-04.en.pdf. Accessed 5 Oct 2018.

Doyle, M.M., S. Garcia, E. Bahati, D. Karamuzi, J.S. Cullor, and S. Nandi. 2015. Microbiological analysis of raw milk in Rwanda. African Journal of Food Science and Technology 6: 141-143.

Ekou, J. 2014. Dairy production and marketing in Uganda: Current status, constraints and way forward. African Journal of Agricultural Research 9 (10): 881-888.

FAO, 2007. Making the informal food sector work for everyone's benefit. Promises and challenges of the informal food sector in developing countries. http:// www.fao.org/docrep/010/a1124e/a1124e00.htm. Accessed 10 Nov 2018.

FAO, 2018. Africa Sustainable Livestock (ASL) 2050 country brief: Uganda - FAO. www.fao.org/3/a-i7503e.pdf. Accessed 1 Oct 2018

Gwandu, S.H., H.E. Nonga, R.H. Mdegela, A.S. Katakweba, T.S. Suleiman, and R. Ryoba. 2018. Assessment of raw cow milk quality in smallholder dairy farms in Pemba Island Zanzibar, Tanzania. Veterinary Medicine International. https:// doi.org/10.1155/2018/1031726.

Hanssen, A.M., B. Kindlund, N.C. Stenklev, A.S. Furberg, S. Fismen, R.S. Olsen, et al. 2017. Localization of Staphylococcus aureus in tissue from the nasal vestibule in healthy carriers. BMC Microbiology. https://doi.org/10.1186/s12866-0170997-3.

Hofi, M. 2011. Contamination in dairy chains and approaches to quality control in Egypt. Internet Journal of Food Safety 13: 264-269.

Holman, E.J., K.S. Allen, J.R. Holguin, M. Torno, and M. Lachica. 2014. A community outbreak of Salmonella enterica serotype Typhimurium associated with an asymptomatic food handler in two local restaurants. Journal of Environmental Health 77: 18-20.

Hosseinzadeh, S., and D.H. Saei. 2014. Staphylococcal species associated with bovine mastitis in the North West of Iran: Emerging of coagulasenegative staphylococci. International Journal of Veterinary Science and Medicine 2 (1): 27-34.

Hudzicki J. 2009. Kirby-Bauer disk diffusion susceptibility test protocol. https://www. asm.org/getattachment/2594ce26-bd44-47f6-8287-0657aa9185ad/Kirby-BauerDisk-Diffusion-Susceptibility-Test-Protocol-pdf.pdf. Accessed 1 Oct 2019. 
Kabirizi, J.M.L. 2006. Effect of integrating forage legumes in smallholder dairy farming systems on feed availability and animal performance. Uganda: Department of Animal Science, Faculty of Agriculture

Kagirita, A.A., A. Baguma, J.T. Owalla, J. Bazira, and S. Majalija. 2017. Molecular characterization of Salmonella from human and animal origins in Uganda. International Journal of Bacteriology. https://doi.org/10.1155/2017/4604789.

Kaneene, J.B., P. Ssajjakambwe, S. Kisaka, P. Vudriko, R. Miller, and J.D. Kabasa. 2016. Improving efficiency of the dairy value chain in Uganda; effect of action research-based interventions on milk quality and safety. Livestock Research for Rural Development. 28, Article \#9. Retrieved September 26, 2019 at: http://www.Irrd.org//rrd28/1/kane28009.html.

Kasozi, K., J. Tingiira, and P. Vudriko. 2014. High Prevalence of Subclinical Mastitis and Multidrug Resistant Staphylococcus aureus Are a Threat to Dairy Cattle Production in Kiboga District (Uganda). Open Journal of Veterinary Medicine 4: 35-43. https://doi.org/10.4236/ojvm.2014.44005.

Kateete, D.P., U. Kabugo, H. Baluku, L. Nyakarahuka, S. Kyobe, M. Okee, et al. 2013. Prevalence and antibiotic susceptibility patterns of bacteria from milkmen and cows with clinical mastitis in and around Kampala, Uganda. PLoS One 8 (5): e63413.

Kjær, A.M., and T. Mwebaze. 2013. Growth and performance of the Ugandan dairy sector: Elites, conflict and bargaining. International Journal of Agriculture Innovation and Research 2 (3): 287-298.

Kondracki, N.L., N.S. Wellman, and D.R. Amundson. 2002. Content analysis: Review of methods and their applications in nutrition education. Journal of Nutrition Education and Behavior 34 (4): 224-230.

Krahulcová, M., K. Lépesová, and L. Bírošová. 2018. Occurence of antibiotic resistant bacteria in raw cow milk from vending machines. Acta Chimica Slovaca 11 (1): 55-59. https://doi.org/10.2478/acs-2018-0009.

Kuipers, A., W.J. Koops, and H. Wemmenhove. 2016. Antibiotic use in dairy herds in the Netherlands from 2005 to 2012. Journal of Dairy Science 99: 1632-1648.

Lowe, R.A., K.E. Barber, J.L. Wagner, A.M. Bell-Harlan, and K.R. Stover. 2017. Ceftriaxone for the treatment of methicillin-susceptible Staphylococcus aureus bacteremia: A case series. Journal of Pharmacology \& Pharmacotherapeutics 8 (3): $140-144$.

Lufafa, A. 2006. Land use and climate change effects on terrestrial stocks in Uganda's cattle corridor. End of project technical report submitted to the Faculty of Agriculture, Makerere University, Uganda.

Makoni, N.F., R. Mwai, T. Redda, A. van der Zijpp, and J. van der Lee. 2014. White gold: Opportunities for dairy sector development collaboration in East Africa. Report CDI-14-006. Wageningen: Centre for Development Innovation, Wageningen http://edepot.wur.nl/307878. Accessed 7 Nov 2018

Mbowa S., Shinyekwa I and Lwanga M. M. 2012. Dairy sector reforms and transformation in Uganda since the 1990s. Economic Policy Research Centre Research Report No. 4. https://ageconsearch.umn.edu/bitstream/148954/2/ research_report4.pdf. Accessed 15 Oct 2018.

Mugendi, A.G. 2013. Influence of milk intermediaries' purchasing strategies on sustainability of small-scale dairy farming in Manyatta constituency, Embu County, Kenya. In Unpublished research report presented in partial fulfilment of the requirements for the award of degree of Master of Arts in project planning and management of the University of Nairobi.

Mukasa, D., C.M. Mugasa, and J.L. Nakavuma. 2012. Antibiotic misuse by farmers in Ngoma subcounty Nakaseke district Uganda. Africa Journal of Animal and Biomedical Sciences 7:9-17.

Ndungu, T.W., P.S. Muliro, M. Omwamba, G. Oosterwijk, and A. Jansen. 2016 Quality control of raw milk in the smallholder collection and bulking enterprises in Nakuru and Nyandarua Counties, Kenya. African Journal of Food Science 10: 70-78.

Nyamwaro, S.O., J. Mugabo, R. Kalibwani, M.M. Tenywa, R. Buruchara, and A.O. Fatunbi. 2018. Innovation opportunities in milk production in Rwanda. Forum for Agricultural Research in Africa (FARA) Research Reports 2(19):17. Accra, Ghana

Oliver, S.P., E.M. Shelton, and B.M. Jayarao. 2011. Impact of antibiotic use in adult cows on antibiotic resistance of veterinary and human pathogens: A comprehensive review. Foodborne Pathogens and Disease 8: 337-355.

Omore, A., and D. Baker. 2011. Integrating informal actors into the formal dairy industry in Kenya through training and certification. In International Livestock Research Institute. Towards priority actions for market development for African farmers. Proceedings of an international conference, 281-291. Nairobi: AGRA and ILRI https://cgspace.cgiar.org/ handle/10568/16492. Accessed 10 Oct 2018.

Ondieki, G.K., J.N. Ombui, M. Obonyo, Z. Gura, J. Githuku, A.B. Orinde, and J.K. Gikunju. 2017. Antimicrobial residues and compositional quality of informally marketed raw cow milk, Lamu West Sub-County, Kenya, 2015. The Pan African Medical Journal. https://doi.org/10.11604/pamj.supp.2017.28.1.9279.

Paraffin, S.A., J.T. Zindove, and M. Chimonyo. 2018. Perceptions of factors affecting milk quality and safety among large- and small-scale dairy farmers in Zimbabwe. Journal of Food Quality. https://doi.org/10.1155/2018/5345874.

Sobur, M.A., A.A.M. Sabuj, R. Sarker, A.M.M.T. Rahman, S.M.L. Kabir, and M.T. Rahman. 2019. Antibiotic-resistant Escherichia coli and Salmonella spp. associated with dairy cattle and farm environment having public health significance. Veterinary World 12 (7): 984-993. https://doi.org/10.14202/vetworld.2019.984-993 Epub 2019 Jul 8. PMID: 31528022; PMCID: PMC6702575.

Ssajjakambwe, P., G. Bahizi, C. Setumba, et al. 2017. Milk hygiene in rural Southwestern Uganda: Prevalence of mastitis and antimicrobial resistance profiles of bacterial contaminants of milk and milk products. Veterinary Medicine International 2017: 6. https://doi.org/10.1155/2017/8710758 Article ID 8710758.

Staal, S.J., and W.N. Kaguongo. 2003. The Ugandan dairy sub-sector. Targeting development opportunities. International Livestock Research Institute https:// cgspace.cgiar.org/bitstream/handle/10568/2089/UgandaDairySubSectorReport.pdf?sequence=1. Accessed 10 Oct 2018.

Sudhir, K., and C. Kalule. 2014. Review milk production and marketing in Uganda: Current situation, requirements and way forward. International Journal of Animal Science, Husbandry and Livestock Production 1 (1): 001-008.

Swai, E.S., and L. Schoonman. 2011. Microbial quality and associated health risks of raw milk marketed in the Tanga region of Tanzania. Asian Pacific Journal of Tropical Biomedicine 1 (3): 217-222.

Thornton, K.P. 2010. Livestock production: Recent trends, future prospects. Philosophical Transactions of the Royal Society B: Biological Sciences 365 (1554): 2853-2867.

Tumwine, G., E. Matovu, J.D. Kabasa, D.O. Owiny, and S. Majalija. 2015. Human brucellosis: Sero-prevalence and associated risk factors in agro-pastoral communities of Kiboga District, Central Uganda. BMC Public Health. https:// doi.org/10.1186/s12889-015-2242-z.

Uganda Bureau of Statistics. 2017: Statistical abstract. https://www.ubos.org/ content/uploads/publications/03_2018Statistical_Abstract_2017.pdf. Accessed 20 Nov 2018

Wangalwa, R., U.C. Tolo, R.G. Kagoro, and W.J. Matofari. 2016. Assessment of onfarm milk handling practices in Mbarara District Southwestern Uganda. African Journal of Dairy Farming and Milk Production 3 (2): 141-148.

Wiley, A.S. 2009. Consumption of milk, but not other dairy products, is associated with height among US preschool children in NHANES 1999-2002. Annals of Human Biology 36 (2): 125-138.

\section{Publisher's Note}

Springer Nature remains neutral with regard to jurisdictional claims in published maps and institutional affiliations.

\section{Submit your manuscript to a SpringerOpen ${ }^{\circ}$ journal and benefit from:}

- Convenient online submission

- Rigorous peer review

- Open access: articles freely available online

- High visibility within the field

- Retaining the copyright to your article

Submit your next manuscript at $\boldsymbol{\nabla}$ springeropen.com 